\title{
The Process of Complexing The Criminal Action Of Planning Murder Performed By Police Investigators
}

\section{Andi Mohamad Akbar Mekuo*) and Amin Purnawan**)}

\author{
*) Universitas Islam Sultan Agung (UNISSULA) Semarang, E-mail: \\ andimohamad.akbarmekuo66@gmail.com \\ **) Faculty of Law Universitas Islam Sultan Agung (UNISSULA) Semarang
}

\begin{abstract}
The police is a figure and protector of the community who at the same time as law enforcement officers have committed a crime that is burdensome and disturbing to the community, namely eliminating a person's life through a planning process that contains elements of violating Article 340 of the Criminal Code for his actions that are declared no longer fit to carry out the police profession in accordance with the Decree. National Police Chief KEP/23VII/2003 concerning the Code of Ethics for the Republic of Indonesia Police. The objectives of the problem in this study are 1) To examine and analyze the settlement of criminal acts committed by unscrupulous members of the Police? 2) To examine and analyze the strategies that need to be taken by the Police to build its image in tackling criminal acts committed by unscrupulous members of the Police? The research approach method used is normative juridical. Sources of data used are secondary data and primary data, secondary data in this study refers to the literature and primary data refers to facts in the field and the results of interviews. The results of the study: 1) Settlement of violations of the police professional code of ethics that resulted in a criminal act will be processed first in a disciplinary hearing due to a dead line or time limit for the implementation of a disciplinary hearing, which is a maximum of 30 (thirty) days as in Article 19 of the Decree of the National Police Chief No. Pol Kep/44/IX/2004. After the implementation of the disciplinary hearing is completed, a trial will be held in the scope of the general court in accordance with Article 2 of PP NO. 3 of 2003 concerning the Implementation of Technical Institutional General Courts for Members of the Indonesian Police,

Keywords: Process; Murder Crime; Police Investigator.
\end{abstract}

\section{Introduction}

In the life of the nation and state, security is a determining factor in the life of the nation and state in carrying out a sovereign and authoritative government, which is the main requirement that supports justice and prosperity and a civilized life in a civil society system based on Pancasila and the 1945 Constitution of the Republic of Indonesia. Domestically, the National Police carries out law enforcement efforts through the process of investigation and criminal investigation, acting as regulated in Act No. 2 of 2002 concerning the Indonesian National Police. ${ }^{1}$

The functions and duties of the Indonesian National Police (hereinafter referred to as Polri) have been regulated in several statutory provisions. Act No. 2 of 2002 concerning the National Police of the Republic of Indonesia expands the

\footnotetext{
$1 \mathrm{Ni}$ Made Srinitri, Umar Ma'ruf, Progressivity of Criminal Handling Fraud And Disease By The Directorate Of The General Criminal Researcher Of Central Java Regional Police (POLDA), Jurnal Daulat Hukum Volume 3 Issue 1, March 2020 ISSN: 2614-560X.
} http://jurnal.unissula.ac.id/index.php/RH/article/view/8777. 
functions and duties of the Police which include maintaining security and public order, law enforcement, protection, shelter, and service to the community by upholding human rights. ${ }^{2}$ Therefore, the National Police must be able to follow and oversee the rapid development of society, along with the spread of the phenomenon of the rule of law, human rights, globalization, democratization, and transparency ${ }^{3}$.

The professional code of ethics is born from within the institution or professional organization itself which is then morally binding for all members who are members of one professional organization with other organizations having different formulations of professional codes of ethics, both the elements of the norm as well as the scope and area of application. Likewise in the Police profession, it has a code of ethics that applies to the police and police function holders. The code of ethics for the Police profession is not only based on professional needs, but has also been regulated normatively in Act No. 2 of 2002 concerning the Indonesian National Police which was followed up by the Regulation of the Chief of Police, ${ }^{4}$ In Articles 34 and 35 of Act No. 2 of 2002 it is stated that:

(1) The attitudes and behavior of Polri officials are bound by the Polri professional code of ethics;

(2) The professional code of ethics of the Police can be a guide for other Police function bearers in carrying out their duties in accordance with the applicable laws and regulations within the Police; and

(3) Provisions regarding the Police Professional Code of Ethics are regulated by a Decree of the Chief of Police.

Furthermore, Article 35 states:

(1) Violations of the Polri professional code of ethics by Polri officials are resolved by the Polri Code of Ethics Commission; and

(2) Provisions regarding the organizational structure and working procedures of the National Police Code of Ethics are regulated by the National Police Chief

In the context of tackling the widespread crime of murder or killing of human life, the Police have a very large role and responsibility for maintaining the security and stability of the State. However, the fact is that the police officers have violated the law. Therefore, the public has lost confidence in the Polri institution, which should be the frontline in terms of public services, in particular providing security and comfort, as well as preventing and reducing the number of criminals. ${ }^{5}$

Based on the description above, the purpose of this research is to examine and analyze the settlement of criminal acts committed by unscrupulous members of the police and to examine and analyze the strategies that need to be taken by the police to build their image in tackling criminal acts committed by unscrupulous members of the police.

\footnotetext{
2 Warsito Hadi Utomo.2015, Hukum Kepolisian di Indonesia. Prestasi. Jakarta, p. 9.

3 Yensih, \& Sukarmi, Hanim, Lathifah. (2019). The Law Strength Of Under Hand Deed That Has Passed By Notary as an Authentic Deed in the Proof of Civil Case in District Court of Cirebon. JURNAL AKTA: Vol. 6, No. 4, 661-668. Retrieved from
} http://jurnal.unissula.ac.id/index.php/akta/article/view/7596

${ }_{4}$ R. abdulsalam, 2011. Penegakan Hukum Di Lapangan Oleh Polri. Dinas Hukum Polri. Jakarta, p. 147 ${ }^{5}$ Budi Setiawan, Penyidikan Terhadap Pelaku Tindak Pidana Pembunuhan Dengan Pemberatan Di Polda Jateng. Jurnal Hukum Khaira Ummah. Vol. 12 No. 4 December 2017. http://jurnal.unissula.ac.id/index.php/ihku/article/download/2308/1736. Accessed July 26, 2021 


\section{Research methods}

The approach method used in this study is a normative juridical approach. The data in this study are secondary data. The secondary data in this study was carried out by means of a literature study. Secondary data includes primary legal materials which in this study are the Criminal Code (KUHP), Act No. 48 of 2009 concerning Judicial Power, Act No. 2 of 2002 concerning the Indonesian National Police, Government Regulation Number 2 of 20092003 concerning the Disciplinary Regulations for Police Members. While the secondary legal materials used in this study are textbooks written by legal experts, legal journals, articles, internet, and other sources that have correlations to support this research. Tertiary legal materials, which consist of an Indonesian Dictionary.

\section{Results and Discussion}

\subsection{Process for the settlement of crimes committed by unscrupulous members of the police}

Examination of members of the Police in the framework of the investigation must still be carried out by taking into account the rank as regulated in Article 5 PP No. 3 of 2003 as follows:

- The enlisted are examined by members of the Indonesian National Police with the lowest rank of NCO.

- The NCO is examined by a member of the Indonesian National Police with the lowest rank of NCO.

- The First Officer is examined by a member of the Indonesian National Police with the lowest rank of NCO.

- Intermediate officers are examined by members of the Indonesian National Police with the lowest rank of First Officer.

- High Officers are examined by members of the Indonesian National Police with the lowest rank of Middle Officers.

For the suspect before the investigation begins against him, there is an obligation from the investigator to notify him of the suspect's right to obtain legal assistance. This is also in accordance with Article 13 PP NO. 3 of 2003 which reads:

1) Suspects or accused members of the Indonesian National Police are entitled to legal assistance at all levels of examination in the judicial process.

2) The State Police of the Republic of Indonesia is obliged to provide legal assistance for suspects or accused members of the State Police of the Republic of Indonesia who are suspected or charged with committing a crime related to the interests of the task.

3) The legal assistance as referred to in paragraph (2) is provided by utilizing legal advisors from the Indonesian National Police and/or other legal advisors.

Settlement in cases of violation of the code of ethics, the Police conduct a disciplinary hearing based on the Decree of the Head of the Indonesian National 
Police No. Pol Kep/44/IX/2004 concerning procedures for disciplinary hearings for members of the Indonesian police. ${ }^{6}$

If there is a violation of the code of ethics that results in a criminal act, the first trial of the violation of the code of ethics is carried out. This is because there is a dead line or time limit for the implementation of the disciplinary hearing, which is a maximum of 30 (thirty) days after the superior who has the right to punish (Ankum) receives the examination file as stipulated in Article 19 of the Decree of the Chief of Police No. Pol Kep/44/IX/2004.

So with this time limit, it is necessary to hold a disciplinary hearing first and then after the disciplinary hearing is completed, the disciplinary hearing's decision file is delegated to the Prosecutor's Office for the process to be forwarded to the general court.

Regarding who checks if there is a violation of the Police Professional Code of Ethics is what is called Ankum. The definition of Ankum is regulated in Article 12 PP No. 2 of 2003 which reads: "A superior who has the right to punish, hereinafter abbreviated as Ankum, is a superior who because of his position is given the authority to impose disciplinary penalties on the subordinates he leads." While Ankum itself has a superior called Ankum superior who has the authority to impose disciplinary penalties for violators which is the result of a decision in a disciplinary hearing. ${ }^{7}$

The stages of the Disciplinary trial as the handling of the Investigated (violators) through several processes, namely:

- Trial preparation;

- Implementation of the trial; and

- Implementation of court decisions.

In this case, the sanctions given to members of the National Police who violate the Police Code of Ethics based on Article 11 paragraph (2) of the Regulation of the National Police Chief Number 7 of 2006 concerning the Professional Code of Ethics of the Indonesian National Police states that the sanctions that can be imposed at the time of the trial decision (verdict). ${ }^{8}$

If the level of violation of the Police's professional code of ethics is included in the qualifications for serious violations and is carried out repeatedly, the examinee can be sentenced to be declared unfit to carry out the profession or function of the police. According to Article 12 paragraph 4 of the Police Professional Code of Ethics, the sanction is an administrative sanction. ${ }^{9}$

Based on Article 12 PP No. 1 of 2003, a member of the National Police is dishonorably discharged from the National Police service if convicted based on a court decision that has permanent legal force and according to the consideration of the competent authority cannot be maintained to remain in the National Police

\footnotetext{
${ }^{6}$ Pudi Rahardi, 2017. Hukum Kepolisian (Profesionalisme dan Reformasi Polri), Laksbang Mediatama. Surabaya, p. 30

7 Kelik Pramudya, 2012. Pedoman Etika Aparat Hukum. Pustaka Yustisia. Yogyakarta, p. 63

${ }^{8}$ Ali Subur dkk, 2013. Pergulatan Profesionalisme Dan Watak Pretorian (Catatan Kontras Terhadap Kepolisian). Ed. IV. Sinar Grifika. Jakarta, p. 41

${ }^{9}$ Bibit Samad Rianto, 2016. Pemikiran Menuju Polri Yang Profesional Mandiri, Berwibawa Dan Dicintai Rakyat. Restu Agung. Jakarta. 13
} 
service. This provision does not explain the minimum amount of punishment imposed on a member of the National Police to be declared unfit to carry out a profession or function in the National Police service. However, in Article 15 of the National Police Chief Regulation No. 7 of 2006 states: "Police members who are sentenced to a minimum prison sentence of 3 (three) months which have permanent legal force can be recommended by members of the National Police Code of Ethics Commission hearing are not fit to be retained as members of the Police."10

If there is a member of the National Police who violates the code of ethics and based on sufficient preliminary evidence he is suspected of committing a crime, then after the disciplinary hearing is completed, then for the crime he will be tried in the scope of the general court as stated in the following articles: ${ }^{11}$

- Article 29 paragraph 1 of Act No. 2 of 2002 concerning the Indonesian National Police: "Members of the Indonesian National Police are subject to the power of the general court."

- Article 2 PP NO. 3 of 2003 concerning the Implementation of Technical Institutional General Courts for Members of the Indonesian National Police which states that: "The criminal justice process for members of the state police of the Republic of Indonesia is generally carried out according to the procedural law applicable in the general court environment".

\subsection{Strategies That Police Need To Take To Build Its Image In Overcoming Crimes Committed By Unscrupulous Police Members}

Strategies to build the image of the Police in tackling criminal acts committed by elements that disturb the community and burden the community can also be carried out by making various improvements to the police related to; police exemplary, police professionalism. The police are a mirror of the law that lives in society. The police are never separated from the community, so it is natural that the public always pays attention to the performance of the police. ${ }^{12}$ Therefore, the example of the police is a determining factor in building the image of the police. Police professionalism can be linked to the right of investigation which according to Article 2 of PP no. 27 of 1983 ; Police officers who are entitled to become investigators are Assistant Second Lieutenant Police / AIPDA, if in the police institution that rank does not exist, then the rank of NCO is determined. Improvements that need to be made regarding the rank of Polri investigators are related to professionalism / intellectualism, namely law undergraduate investigators. The reason is that as part of the criminal justice system, apart from

\footnotetext{
10 Sadjijono, 2010. Memahami Hukum Kepolisian. Laksbang PRESSindo. Yogyakarta, p. 98

11 Yeremia Toga Sinaga, 2018. Rekontruksi Kasus Pembunuhan yang Dilakukan Oknum Kepolisian Diwilayah Hukum Kepolisian Resor Kota Denpasar Berbasis Keadilan. https://ojs.unud.ac.id/index.php/kerthawicara/article/download/48435/28869, Accessed July 26, 2021

12Korry, 2016. Memacu Kemitraan Polri dan Masyarakat Menangkal Gangguan Kamtibnas dalam Merenungi Kritik terhadap Polri. Cipta Manunggal. Jakarta, p. 142
} 
prosecutors and judges, only the police do not require quality education/ intellectualism. ${ }^{13}$

Prosecutors as public prosecutors have law degrees, as well as judges. So it is natural that as an effort to reform the police to build the image of the police, it is recommended that the police investigators also hold a law degree. The police are the spearhead of the criminal justice system, of course the issue of professionalism/intellectualism is a major concern. The police's perception of criminal law also needs improvement, because the police must understand correctly that criminal law is not the only means of overcoming criminal acts. Criminal law is like a double-edged sword (criminal) on the one hand protecting legal interests, on the other hand injuring legal interests. Therefore, we must be extra careful in using criminal law need to understand, that the use of criminal law is only symptomatic / overcoming symptoms, not tackling the causes of criminal acts. The causes of criminal acts are beyond the reach of criminal law. ${ }^{14}$

Of all the functions of the police, which are law enforcement officers, many officers consider it to be frustrating among members. ${ }^{15}$ In the public's view, the perpetrators of law violations committed by police officers are not criminals at all or are assumed to be in a position of immunity from the law. Therefore, the public always believes that every member of the police force when committing a crime will receive forgiveness from the law, which is often found in the community, who underestimates the task of the police, which results in a decline in the image of the police in society. ${ }^{16}$ In this case, the police will remain as law enforcers who must be able to act fairly and professionally in carrying out their profession in the future. Problems related to criminal acts committed by police officers who are considered disturbing and burdensome to the community will still be processed by the police agency ${ }^{17}$. Many officers assume that crimes are uncovered and even solved through law enforcement and investigation processes. ${ }^{18}$

According to Soedjono Sukanto, with the capacity building strategy and implementation pattern as described above, it is hoped that every form and type of crime that occurs or will occur can be handled effectively and efficiently. Especially for the types of crimes that use technological aspects, the Police are also ready with their criminal laboratories, which are in charge of scientifically proving crimes. With the functioning of the criminal laboratory, laboratory detection of every crime that

\footnotetext{
13 Al. Wisnubroto, 2002. Peradilan Pidana, Proses Persidangan Perkara Pidana. Galaxi Puspa Mega. Bekasi, p. 63

14Sadjijono, 2015. Mengenal Hukum Kepolisian (Perspektif Kedudukan dan Hubungannya dalam Hukum Administrasi). Laksbang Mediatama. Surabaya, p. 60

15Pudi Rahardi, 2014. Hukum Kepolisian (Kemandirian, Profesionalisme dan Reformasi POLRI). Laksbang Grafika. Surabaya, p. 168

16Bibit Samad Rianto, 2016. Pemikiran Menuju Polri Yang Profesional Mandiri, Berwibawa Dan Dicintai Rakyat. Restu Agung. Jakarta. 13

17 A Chuasanga, Ong Argo Victoria. (2019). Legal Principles Under Criminal Law in Indonesia Dan Thailand, Jurnal Daulat Hukum, Vol $2, \quad$ No 1 (2019) http://jurnal.unissula.ac.id/index.php/RH/article/view/4218

18 S. Rajab, 2003. Kedudukan dan Fungsi Polri dan Fungsi Polisi Republik Indonesia Dalam Sistem Ketatanegaraan. Utomo. Bandung, p. 10.
} 
uses technological aspects, will obtain a high degree of certainty for the sake of proof. ${ }^{19}$ There are several aspects that must be fulfilled, including:

- Trust Aspect

- Aspects of Community Support

- Aspects of Law Enforcement Protection Target

\section{Closing}

Settlement of violations of the code of ethics of the police profession that results in criminal acts will be processed first in a disciplinary hearing due to a dead line or time limit for the implementation of a disciplinary hearing, which is a maximum of 30 (thirty) days as stated in Article 19 of the Decree of the Chief of the National Police No. Pol Kep/44/IX/2004. After the implementation of the disciplinary hearing is completed, a trial will be held in the scope of the general court in accordance with Article 2 of PP No. 3 of 2003 concerning the Implementation of Technical Institutional General Courts for Members of the Indonesian National Police and the strategies that need to be taken by the Police to build its image in tackling criminal acts committed by unscrupulous members of the Police are that the Police are able to realize familial conditions in providing services to the community and are more responsive, sympathetic and does not discriminate against anyone dealing with the police. Thus the Police must try to identify the development of the situation in the future, what has changed, what crimes have occurred; and how to control it, taking into account the strengths and weaknesses of the Police themselves. From this, the Police will be able to restore their image in the community.

Furthermore, suggestions can be made that the Police should remain committed to upholding the rule of law in the absence of discrimination by applying the principle that whoever the guilty member will be processed according to applicable law and based on the existing mechanism where the police will not cover up the guilty member and the public must know what is happening in the case of the police, and in every coaching for each member of the police, more emphasis should be placed on moral attitudes and behavior in accordance with the code of ethics. This is because the police is the closest institution to the community where every action will always be judged directly by the community.

\section{References}

\section{Journals}

[1] A Chuasanga, Ong Argo Victoria. (2019). Legal Principles Under Criminal Law in Indonesia Dan Thailand, Jurnal Daulat Hukum, Vol 2, No 1 (2019) http://jurnal.unissula.ac.id/index.php/RH/article/view/4218

[2] Budi Setiawan, Penyidikan Terhadap Pelaku Tindak Pidana Pembunuhan Dengan Pemberatan Di Polda Jateng. Jurnal Hukum Khaira Ummah. Vol. 12 No. 4 December 2017

\footnotetext{
${ }^{19}$ Barda Nawawi Arief, 2001. Masalah Penegakan Hukum dan Kebijakan Penanggulangan Kejahatan. Citra Aditya Bakti. Bandung, p. 73
} 
[3] Ni Made Srinitri, Umar Ma'ruf, Progressivity Of Criminal Handling Fraud And Disease By The Directorate Of The General Criminal Researcher Of Central Java Regional Police (POLDA), Jurnal Daulat Hukum Volume 3 Issue 1, March 2020 ISSN: 2614-560X

[4] Yeremia Toga Sinaga, 2018. Rekontruksi Kasus Pembunuhan yang Dilakukan Oknum Kepolisian Diwilayah Hukum Kepolisian Resor Kota Denpasar Berbasis Keadilan. https://ojs.unud.ac.id/index.php/kerthawicara/article/download/48435/28 869.

[5] Yensih, \& Sukarmi, Hanim, Lathifah. (2019). The Law Strength Of Under Hand Deed That Has Passed By Notary as an Authentic Deed in the Proof of Civil Case in District Court of Cirebon. JURNAL AKTA: Vol. 6, No. 4, 661-668. Retrieved from http://jurnal.unissula.ac.id/index.php/akta/article/view/7596

\section{Book}

[1] Al. Wisnubroto, 2002. Peradilan Pidana, Proses Persidangan Perkara Pidana. Galaxi Puspa Mega. Bekasi.

[2] Ali Subur dkk, 2013. Pergulatan Profesionalisme Dan Watak Pretorian (Catatan Kontras Terhadap Kepolisian). Ed. IV. Sinar Grifika. Jakarta.

[3] Bambang Sungguno, 2011. Metodologi Penelitian HukumNormatif. Raja Grafindo Persada. Jakarta.

[4] Barda Nawawi Arief, 2001. Masalah Penegakan Hukum dan Kebijakan Penanggulangan Kejahatan. Citra Aditya Bakti. Bandung.

[5] Bibit Samad Rianto, 2016. Pemikiran Menuju Polri Yang Profesional Mandiri, Berwibawa Dan Dicintai Rakyat. Restu Agung. Jakarta.

[6] Kelik Pramudya, 2012. Pedoman Etika Aparat Hukum. Pustaka Yustisia. Yogyakarta.

[7] Korry, 2016. Memacu Kemitraan Polri dan Masyarakat Menangkal Gangguan Kamtibnas dalam Merenungi Kritik terhadap Polri. Cipta Manunggal. Jakarta.

[8] Pudi Rahardi, 2014. Hukum Kepolisian (Kemandirian, Profesionalisme dan Reformasi POLRI). Laksbang Grafika. Surabaya.

[9] Bibit Samad Rianto, 2016. Pemikiran Menuju Polri Yang Profesional Mandiri, Berwibawa Dan Dicintai Rakyat. Restu Agung. Jakarta.

[10] Pudi Rahardi, 2017. Hukum Kepolisian (Profesionalisme dan Reformasi Polri), Laksbang Mediatama. Surabaya.

[11] R. abdulsalam, 2011. Penegakan Hukum Di Lapangan Oleh Polri. Dinas Hukum Polri. Jakarta.

[12] Ronny Hanitijo Soemitro, 1990. Metode Penelitian Hukum dan Jurimetri, Ghalia Indonesia. Jakarta.

[13] S. Rajab, 2003. Kedudukan dan Fungsi Polri dan Fungsi Polisi Republik Indonesia Dalam Sistem Ketatanegaraan. Utomo. Bandung.

[14] Sadjijono, 2010. Memahami Hukum Kepolisian. Laksbang PRESSindo. Yogyakarta.

[15] Sadjijono, 2015. Mengenal Hukum Kepolisian (Perspektif Kedudukan dan Hubungannya dalam Hukum Administrasi). Laksbang Mediatama. Surabaya.

[16] Warsito Hadi Utomo.2015, Hukum Kepolisian di Indonesia. Prestasi. Jakarta. 


\section{Regulation}

[1] Criminal Code (KUHP)

[2] Act No. 2 of 2002 concerning the National Police of the Republic of Indonesia

[3] Act No. 48 of 2009 concerning Judicial Power

[4] Government Regulation Number 2 of 2003 concerning Discipline of Members of the Indonesian National Police

[5] Government Regulation Number 1 of 2003 concerning Dismissal of Members of the Indonesian National Police

[6] Perkapolri Number 14 of 2011 concerning the Professional Code of Ethics of the Indonesian National Police 